\title{
Correction to: An uncommon outbreak of irritant contact dermatitis caused by rubber accelerators: a historical cohort study
}

\author{
Attasit Rattanarak $^{1} \cdot$ Naesinee Chaiear $^{1} \mathbb{D} \cdot$ Jitladda Sakdapipanich ${ }^{2,3} \cdot$ Jinjutha Wiriyanantawong $^{2}$
}

Published online: 27 September 2019

(c) The Malaysian Rubber Board 2019

Correction to: Journal of Rubber Research

https://doi.org/10.1007/s42464-019-00023-w

The original version unfortunately contained mistakes. The institution of the author Jitladda Sakdapipanich was wrong.

Correct it should be:

${ }^{2}$ Department of Chemistry and Center of Excellence for Innovation in Chemistry, Faculty of Science, Mahidol University, Bangkok 10400, Thailand;

${ }^{3}$ Institute of Molecular Biosciences, Mahidol University at Salaya, Putthamonthon 4 Road, Salaya, Nakornpathom 73170, Thailand.

The original article can be found online at https://doi.org/10.1007/ s42464-019-00023-w.

Naesinee Chaiear

naesinee@kku.ac.th

Attasit Rattanarak

athasit98@gmail.com

Jitladda Sakdapipanich

jitladda.sak@mahidol.ac.th

Jinjutha Wiriyanantawong

jinjutha.wir@gmail.com

1 Division of Occupational Medicine, Department

of Community Medicine, Faculty of Medicine, Khon Kaen

University, Khon Kaen 40002, Thailand

2 Department of Chemistry and Center of Excellence for Innovation in Chemistry, Faculty of Science, Mahidol

University, Bangkok 10400, Thailand

3 Institute of Molecular Biosciences, Mahidol

University at Salaya, Putthamonthon 4 Road,

Salaya, Nakornpathom 73170, Thailand 